\title{
THE ROLE OF PROTOZOAL INFESTATIONS IN CHRONIC INFLAMMATION EXACERBATIONS IN PATIENTS WITH GENITOURINARY PATHOLOGY
}

\author{
Pavlo Fedorych \\ Department of Military General Practice and Family Medicine \\ Ukrainian Military Medical Academy of Ministry of Education of Ukraine \\ 24 Melnikova str., Kyiv, Ukraine, 03049 \\ pvf9@meta.ua \\ Gennadiy Mavrov \\ Department for the study of HIVIAIDS effect on STI problem \\ SI Institute of Dermatology and Venereology of the National Academy of Medical Sciences of \\ Ukraine \\ 7/9 Chernyshevskogo str., Kharkiv, Ukraine, 61057 \\ Department of Dermatovenereology and HIVIAIDS \\ Kharkiv Medical Academy of Postgraduate Education \\ 58 Amosova str., Kharkiv, Ukraine, 61176 \\ uniidiv@gmail.com
}

\begin{abstract} nary clinic.

The aim: to study the prevalence of protozoal infestations in cases of acute inflammatory exacerbations in genitouri-

Materials and methods. The method of polymerase chain reaction was used to examine 158 subjects with chronic inflammation of the genitourinary system exacerbations.

Results. Infestation of the genitourinary system was identified in 72 patients (45.6\%). Trichomonas infestation was identified in $63(87.5 \%)$ of them. Trichomonas vaginalis was identified in 1 (1.4\%) subject. Other Trichomonas species - in 62 (86.1\%) subjects. $12(16.7 \%)$ had Trichomonas tenax, and $50(69.4 \%)$ - Pentatrichomonas hominis. Giardia lamblia was identified in 9 patients - i. e. in $12.5 \%$ individuals with infestation of the genitourinary system, or in $5.7 \%$ among subjects examined for STIs in this study.

Conclusions: High level of Trichomonas infestation of the genitourinary system was identified in subjects with of chronic inflammatory exacerbations of the genitourinary system. In most cases, infestations were caused by Trichomonas species other than Trichomonas vaginalis, as well as by Giardia lamblia. An assumption about a certain role of these pathogens in the onset or further course of inflammatory diseases of the genitourinary system was made.
\end{abstract}

Keywords: Trichomonas vaginalis, Trichomonas tenax, Pentatrichomonas hominis, Giardia lamblia, sexually transmitted infections, infestations.

\section{Introduction}

Parasitic infestation is a medical and biological term that determines the totality of processes occurring during the infectious process: interaction between the pathogen and the host organism, when parasite acts as causative agent. In epidemiology and parasitology, infestation means either the fact of parasites' penetration into the host organism, i. e. infection, usually, with parasitic fungi, protozoa, helminths, or diseases caused by parasitic pathogens: fungal infestations, protozoal infestations. These diseases are also classified as infectious [1].

Among protozoal infestations of the genitourinary system, genus Trichomonas has the major role [2]. Currently, it is considered that humans can be hosts of three species of Trichomonas: Trichomonas tenax (elongata), Pentatrichomonas hominis (abdominalis), Trichomonas vaginalis [3]. Trichomonas tenax is found in the oral cavity, decayed teeth, as well as with periodontitis. Pentatrichomonas hominis is the commensal of the large intestine [4]. Until recently, it was believed that the only Trichomonas species that may occupy the urogenital tract is Trichomonas vaginalis 
[5]. In modern conditions, there are certain difficulties in the management of genitourinary trichomoniasis, particularly the diagnostics and treatment [6]. Atypical forms of Trichomonas vaginalis may cause some problem in laboratory diagnostic as they rather variable in shape, size, presence of flagella and nuclei [7]. In addition, atypical forms of Trichomonas vaginalis have certain external similarity to other protozoa [8] (Fig. 1, 2).

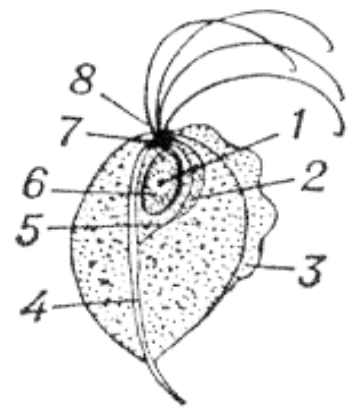

Fig. 1. T. vaginalis:1 - nucleolus; 2 - parabasal apparatus; 3 - undulating membrane; 4 - axostil; 5 - parabasal thread; 6 - nucleus; 7 - blepharoplast; 8 - front flagella $[3,4]$

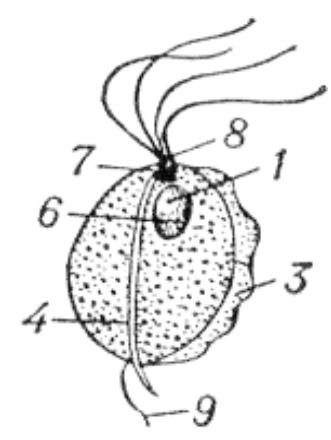

Fig. 2. T. hominis: 1 - nucleolus; 3 - undulating membrane; 4 -axostil; 5 -parabasal thread; 6 - nucleus; 7 - blepharoplast; 8 - front flagella; 9 -- ultimate flagellum [3, 4]

Over the past few decades, living conditions of human population have changed significantly [9]. However, as is known, the idea of pathogenicity of some microorganisms that can be found in human genitourinary system, e.g. mycoplasmas and gardnerellas, has changed as well [10]. It was assumed that certain protozoa could also undergo changes and acquire an ability to colonize the human genitourinary system. By studying the relevant literature data [10], it was assumed that certain protozoa: Trichomonas tenax, Pentatrichomonas hominis, and Giardia lamblia could have acquired such properties.

Perhaps such properties could occur when these pathogens enter the genitourinary system with unprotected barriers, respectively, oral and anal sex, which have become widespread in the intimate relationships of our contemporaries. Oral sex today is usual sexual practice of heterosexual and homosexual couples. It has been proven that oral sex is a way of transmitting gonorrhoea, syphilis, and some other infectious agents $[2,7]$. Partners who practice Felatio are at risk of acquiring an infection per os. Cunnilingus, presumably, leads to bacterial vaginosis. With the spread of oral sex practices, the latter became an important potential route for the transmission of genital pathogens [2]. The National Centre for Health Statistics USA provided a detailed report based on the study of sexual behaviour of 12571 men and women aged 15 to 44 years. As a result of this study, it was found that about $12 \%$ of boys and $10 \%$ of girls aged $15-19$ years practiced heterosexual oral sex without entering into traditional vaginal intercourse. Of the men between the ages of 25 and $44.9 \%$ practiced oral sex, and $40 \%$ had anal sex with women. Among women, the percentage of those who practice anal and oral sex was similar. According to the survey, $3 \%$ of American men in the last 12 months had anal and / or oral sex with other men, and $4 \%$ of women entered into sexual relationships with other women [11]. 
Back in 1930-s, intestinal and oral Trichomonas were considered pathogens of the genitourinary system on a par with Trichomonas vaginalis [12]. In our century, most researchers identified Trichomonas tenax or Pentatrichomonas hominis only in isolated cases, and mostly in women. Therefore, they were inclined to consider these organism either as an accidental contamination or as a transient microflora after oral or anal sex that took place shortly before the biological material was taken for the corresponding test $[13,14]$. However, there is an opinion that human genitourinary system may be colonized by Trichomonas tenax and Pentatrichomonas hominis [12]. As for lamblia, detection of Giardia lamblia in the genitourinary system of STI patients can reach about $6 \%$ [15]. There were some reports in the appropriate literature during last decade about Giardia lamblia detection in the genitourinary system, especially in homosexual men $[16,17]$. In this case, the syndrome of disorders in the urogenital tract is characterized by urethritis. The prostate and bladder may also be affected. Difficulties in urination, sexual function disorders, and the sperm impairments, up to infertility may occur [2]. Because of itching, subjects scratch the perineum, external genitals, so excoriations may be found in these areas [18].

Given the urgency of the problem of urogenital trichomoniasis and the results of pilot studies at the present stage, there was a need for a thorough study of the Trichomonas representatives in terms of their ability to colonize the genitourinary system of humans and to become pathogenic while. It was established that three different species of Trichomonas and Giardia lamblia may be found in human genitourinary system $[2,19]$. In view of this, a new scientific problem arose regarding the possibility of infestation of the genitourinary system with different species of Trichomonas and Lamblia. Addressing this issue is extremely important for determine the possible pathogenicity of Trichomonas tenax, Pentatrichomonas hominis and Giardia lamblia for human genitourinary system.

\section{Aim of research}

Study the prevalence of protozoal infestations in patients with acute exacerbations of chronic inflammatory genitourinary impairments.

\section{Materials and methods}

The study group was formed from among 158 STI subjects of both sexes, who contacted Oleksandrivska Clinical Hospital (Kyiv) for specialized medical care during 2013-2017 because of acute exacerbations of chronic inflammations in the genitourinary system. The final sample of 72 subjects was randomly formed retrospectively upon the detection of urogenital infestations in each subject. Thus, the study group consisted of 26 (36.1\%) females and 46 males (63.9\%). Mean age was $32 \pm 2.5$. All examined subjects had chronic urogenital infections and severe clinical pattern of the disease with corresponding manifestations and complaints. Each of them signed an informed consent to take part in the study.

The method of polymerase chain reaction (PCR) was used to identify Trichomonas vaginalis. Real-time PCR, as the most specific and sensitive method, was used to identify Pentatrichomonas hominis, Trichomonas tenax and Giardia lamblia in the subjects' genitourinary system. Biological material for testing for urogenital infections was sampled in accordance with the current guidelines [15]. Upon recording, test samples were placed in Eppendorf tubes containing $1 \mathrm{ml}$ of sterile physiological saline and stored frozen at $-10{ }^{\circ} \mathrm{C}$ prior to testing. DT-96 amplifier (SPA DNK Technology, Russian Federation) was used. Primers certified in Ukraine were used to identify Trichomonas vaginalis. Original primers recently developed in Ukraine for such tests were used to identify Pentatrichomonas hominis, Trichomonas tenax and Giardia lamblia [20, 21].

Statistical analysis was carried out using Statistica for Windows (version 10.0). The level of reliability was adopted as $\mathrm{P}<0.01$

\section{Result}

Protozoal infestation of the genitourinary system was identified in $45.6 \%$ (72 of 158) study subjects with chronic genitourinary inflammation exacerbations. Trichomonas infestation was identified in 63 (87.5\% of all infested) of 72 subjects of the study group. Trichomonas vaginalis was iden- 
tified in 1 subject (1.4\% of all infested). Other Trichomonas species - in 62 (86.1\% of all infested) subjects. Furthermore, 12 (16.7\% of all infested) subjects had Trichomonas tenax and 50 (69.4\% of all infested) - Pentatrichomonas hominis. The level of Giardia lamblia detection in the study group was $12.5 \%$ of all infested ( 9 subjects). Out of total STI subjects examined $-5.7 \%$ (Table 1).

Table 1

Protozoal infestation of the genitourinary system of 158 subjects with chronic genitourinary inflammation exacerbations

\begin{tabular}{cccc}
\hline Pathogen & $\mathbf{N}$ & $\mathbf{\%} \pm \mathbf{S}_{\%}$ & $\begin{array}{c}\text { Reliability of differences from } \\
\text { Trichomonas vaginalis occurrence }(\mathbf{P})\end{array}$ \\
\hline All infestation & 72 & $45.6 \pm 4.0$ & - \\
Trichomonas vaginalis & 1 & $0.63 \pm 0.6$ & $<0.0001$ \\
Giardia lamblia & 9 & $5.7 \pm 1.8$ & $<0.0001$ \\
Trichomonas tenax & 12 & $7.6 \pm 2.1$ & $<0.0001$
\end{tabular}

\section{Discussion}

In the process of in-depth study of methods for diagnosis of trichomoniasis, our attention has led to a certain number of inconsistencies in the identification of this agent, provided that different diagnostic methods are used simultaneously [4, 7]. Thus, with the simultaneous use of optical microscopy and polymerase chain reaction (PCR) in the same patients and the same biological material, the results are significantly differed. Moreover, contrary to expectations, the method of optical microscopy was more effective than PCR in spite of PCR much greater specificity and sensitivity than optic microscopy. Some experts from different countries have made assumptions about the possibility of the protozoa other than Trichomonas vaginalis can propagate in genitourinary system $[4,6]$. There are data on the detection of Pentatrichomonas hominis and Trichomonas tenax in different organs and systems (18.8 \% of the infection in the case group) [22, 23]. However, cases of detection of Trichomonas tenax and Pentatrichomonas hominis in the genitourinary system of humans were sporadic and were considered as a result of contamination during the collection of biological material. Although data from 47 studies showed that $T$. tenax prevalence in diseased periodontium ranged from 0 to $94 \%$ [24].

According to the results of this pilot study, trichomonads and lamblia were identified in subjects with chronic inflammatory syndromes of the genitourinary system, namely, in almost half of all cases. This fact is difficult to ignore. In addition, the clear clinical pattern of STIs in the examined subjects indicated a certain role of Trichomonas species, which were not Trichomonas vaginalis, as well as Giardia lamblia, in the onset and/or progress of inflammatory diseases of the genitourinary system. Strict compliance by the subjects with the terms of the study, including sexual abstinence for at least 2 days, virtually ruled out the occurrence of these protozoa as transient microflora in the genitourinary system. The multistage design and duration of the study made contamination of the tested material less probable. The fact of exacerbation of the chronic inflammatory process in the genitourinary system enabled us to assume a certain role of these microorganisms as factors contributing to the onset and/or progress of genitourinary infections. Quite possibly, elimination of these parasites could improve management of the genitourinary inflammation, and emphasize the need for sexual partners' treatment. However, no exhaustive evidence of pathogenicity of Trichomonas tenax or Pentatrichomonas hominis for human genitourinary system was found so far.

\section{Conclusion}

1. High level (45.6\%) of protozoal infestation with Trichomonas tenax, Pentatrichomonas hominis and Giardia lamblia in the absence of Trichomonas vaginalis in subjects with exacerbations of chronic inflammations of the genitourinary system was identified. 
2. Some assumption about a certain role of Trichomonas tenax, Pentatrichomonas hominis and Giardia lamblia in the onset and/or progress of genitourinary infections inflammatory diseases of human genitourinary system was made.

\section{References}

[1] Parazytarna invaziia. Wikipedia. Available at: https://uk.wikipedia.org/wiki/Паразитарна_інвазія

[2] Mavrov, I. I. (2002). Polovyie bolezni [Sexually transmitted diseases]. Moscow: AST-PRESS KNIGA, 752.

[3] Bykov, A. S., Vorobyev, A. A., Zverev, V. V. et. al. (2008). Atlas po meditsinskoy mikrobiologii, virusologii i immunologii [Atlas on medical microbiology, virology and immunology]. Moscow: Medical Information Agency LLC, 340.

[4] Neimark, S. L., Neimark, O. S. (2014). Dyskusiyni problemy diahnostyky ta likuvannya trykhomonadnoy infektsiyi [Discussion problems of diagnosis and treatment of trichomonas infection]. Asotsiatsiya akusheriv i hinekolohiv Ukrayiny [Association of Obstetricians and Gynecologists of Ukraine], 1-2, 236-239.

[5] Gorchakov, D. A. (2014) Patogeneticheskie osobennosti urogenitalnogo trihomoniaza v gendernom aspekte [Pathogenetic features of urogenital trichomoniasis in gender aspect]. Saratov, 134.

[6] Hobbs, M. M., Sena, A. C. (2013). Modern diagnosis of Trichomonas vaginalisinfection: Table 1. Sexually Transmitted Infections, 89 (6), 434-438. doi: http://doi.org/10.1136/sextrans-2013-051057

[7] Savicheva, A. M. et. al. (2011). Laboratornaya diagnostika urogenital'nogo trikhomoniaza: Metodicheskiye ukazaniya [Laboratory diagnosis of urogenital trichomoniasis: Methodological guidelines]. Saint Petersburg: N-L, 36.

[8] Bachmann, L. H., Hobbs, M. M., Sena, A. C., Sobel, J. D., Schwebke, J. R., Krieger, J. N. et. al. (2011). Trichomonas vaginalis Genital Infections: Progress and Challenges. Clinical Infectious Diseases, 53, 160-172. doi: http://doi.org/10.1093/cid/cir705

[9] Schwebke, J. R., Gaydos, C. A., Davis, T., Marrazzo, J., Furgerson, D., Taylor, S. N. et. al. (2017). Clinical Evaluation of the Cepheid Xpert TV Assay for Detection of Trichomonas vaginalis with Prospectively Collected Specimens from Men and Women. Journal of Clinical Microbiology, 56 (2). doi: http://oi. org/10.1128/jcm.01091-17

[10] Ronald, A., Kuypers, J., Lukehart, S. A., Peeling, R. W., Pope, V. (2006). Excellence in sexually transmitted infection (STI) diagnostics: recognition of past successes and strategies for the future. Sexually Transmitted Infections, 82, 47-52. doi: http://doi.org/10.1136/sti.2006.023911

[11] The National Centre for Health Statistics USA. Available at: https://www.cdc.gov/nchs/index.htm/

[12] Bland, B. P., Rakoff, A. E. (1937). The incidence of trichomonads in the vagina, mouth and rectum evidence that vaginal trichomonads do not originate in the mouth or intestine. Journal of the American Medical Association, 108 (24), 2013-2016. doi: http://doi.org/10.1001/jama.1937.02780240005003

[13] Carlton, J. M., Hirt, R. P., Silva, J. C., Delcher, A. L., Schatz, M., Zhao, Q. et. al. (2007). Draft Genome Sequence of the Sexually Transmitted Pathogen Trichomonas vaginalis. Science, 315 (5809), 207212. doi: http://doi.org/10.1126/science.1132894

[14] Crucitti, T., Abdellati, S., Ross, D. A., Changalucha, J., Dyck, E., Buve, A. (2004). Detection of Pentatrichomonas hominis DNA in biological specimens by PCR. Letters in Applied Microbiology, 38 (6), 510-516. doi: http://doi.org/10.1111/j.1472-765x.2004.01528.x

[15] Centers of Disease Control and Prevention. Sexually transmitted diseases treatment guidelines (2015). MMWR, 64 (3), 72-75.

[16] Di Benedetto, M. A., Di Piazza, F., Amodio, E., Taormina, S., Romano, N., Firenze, A. (2012). Prevalence of sexually transmitted infections and enteric protozoa among homosexual men in western Sicily (south Italy). Journal of Preventive Medicine and Hygiene, 53, 181-185.

[17] Hart, G. J., Elford, J. (2010). Sexual risk behaviour of men who have sex with men: emerging patterns and new challenges. Current Opinion in Infectious Diseases, 23 (1), 39-44. doi: http://doi.org/10.1097/ qco.0b013e328334feb1

[18] Ojonoma, O. L. (2008). A review of sexually transmitted diseases (STDs) of parasitic origin: The case of giardiasis. African Journal of Biotechnology, 7 (25), 4979-4981.

[19] Fedorych, P. V., Zelenyi, S. B., Sadovska, O. A., Dudikova, K. V. (2017). Porivniannia efektyvnosti diahnostyky trykhomoniazu za kulturalnym metodom ta metodom polimeraznoi lantsiuhovoi reaktsii 
z vykorystanniam praimeriv dlia vyiavlennia Trichomonas vaginalis, Trichomonas tenax ta Pentatrichomonas hominis [Comparison of Trichomoniasis diagnostic effectiveness by culture method and polymer chain reaction method using primers to detect Trichomonas vaginalis, Trichomonas tenax and Pentatrichomonas hominis]. Ukrainskyi zhurnal dermatolohii, venerolohii, kosmetolohii, 1 (64), 65-69.

[20] Fedorych, P. V., Zelenyi, S. B. (2016). Pat. 110759 UA. Sposib vyznachennia prysutnosti Pentatrichomonas hominis u doslidzhuvanomu zrazku ta nabir praimeriv dlia yoho zdiisnennia [Method for determining the presence of Pentatrichomonas hominis in the test sample and the set of primers for its implementation.]. MPK S12Q1/68 (2006.01), S12Q1/04 (2006.01), S12N15/11 (2006.01), S12R1/90 (2006.01). No. a201501255; declareted: 16.02.2015; published: 10.02.16, Bul. No. 3.

[21] Lyisak, V. V., Fomina, O. V. (2014). Sistematika mikroorganizmov [Systematization of microorganisms]. Minsk: BGU, 304.

[22] Meloni, D., Mantini, C., Goustille, J., Desoubeaux, G., Maakaroun-Vermesse, Z., Chandenier, J. et. al. (2011). Molecular identification of Pentatrichomonas hominis in two patients with gastrointestinal symptoms. Journal of Clinical Pathology, 64 (10), 933-935. doi: http://doi.org/10.1136/jcp.2011.089326

[23] Mehr, A. K., Zarandi, A., Anush, K. (2015). Prevalence of Oral Trichomonas tenax in Periodontal Lesions of Down Syndrome in Tabriz, Iran. Journal of Clinical and Diagnostic Research, 9 (7), 88-90. doi: http://doi.org/10.7860/jcdr/2015/14725.6238

[24] Marty, M., Lemaitre, M., Kemoun, P., Morrier, J. J., Monsarrat, P. (2017) Trichomonas tenax and periodontal diseases: a concise review Parasitology, 144 (11), 1417-1425. doi: http://doi.org/10.1017/ s0031182017000701

\title{
ESTIMATION OF RESERVES FOR IMPROVING THE RESULTS OF PATIENTS WITH MULTIPRESISTANT PULMONARY TUBERCULOSIS IN THE APPLICATION OF SURGICAL METHODS BASED ON ANALYSIS OF THE EFFICIENCY OF CONSERVATIVE TREATMENT OF A SPECIFIED COHORT
}

\author{
Oleg Khmel \\ Department of Surgical Treatment of Tuberculosis and NLL \\ State Enterprise "F. G. Yanovsky National Institute of Phthisiology and Pulmonology of \\ NAMS of Ukraine" \\ 10 M. Amosova str., Kyiv, Ukraine, 03680 \\ Khmel.Ol@gmail.com \\ Igor Kalabukha \\ Department of Thoracic Surgery \\ State Enterprise "F. G. Yanovsky National Institute of Phthisiology and Pulmonology of \\ NAMS of Ukraine“ \\ 10 M. Amosova str., Kyiv, Ukraine, 03680 \\ dr.kalabukha@gmail.com \\ Vladimir Ivashchenko \\ Department of Thoracic Surgery \\ State Enterprise "F. G. Yanovsky National Institute of Phthisiology and Pulmonology of \\ NAMS of Ukraine“" \\ 10 M. Amosova str., Kyiv, Ukraine, 03680 \\ ivaschenko@ifp.kiev.ua
}

